Kharkiv: KhDAK [in Ukrainian].

12. Ilganaev, V.A.(Eds.). (2009). Social Communications: Theory, Methodology, Activity: dictionaryreference book. Kharkiv: Hor.typ. [in Russian].

Shvetsova-Vodka, G. M. (2010). Documentary communication as an object of the general theory of documentology. Retrieved from http://nbuv.gov.ua/UJRN/bdi_2010_2_9 [in Ukrainian].

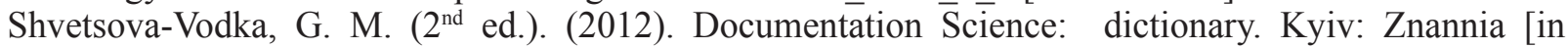
Ukrainian].

УДК 004.738.1:352.071(477.44)

Бойко Наталія Вячеславівна, аспірантка Національної академії керівних кадрів культури і мистецтв natasha.boiko87.16@gmail.com https://orcid.org/0000-0003-4643-5299

\title{
ВЕБ-САЙТ ЯК СКЛАДОВА ДОКУМЕНТНО-КОМУНІКАЦІЙНОГО ПРОСТОРУ ОРГАНІВ МІСЦЕВОГО САМОВРЯДУВАННЯ: СТРУКТУРА, РЕСУРСИ, ЗМІСТ
}

Мета роботи. Дослідити структуру сайту та зміст інформаційних ресурсів представлених на веб-сайті Вінницької міської ради; зробити висновки щэодо ролі інформащійно-аналітичних документів в документно-комунікаиійній системі органів місиевого самоврядування. Методологія дослідження базується на застосуванні загальнонаукових методів: аналізу, синтезу, логічного методу, методу візуалізачії результатів дослідження. Названі методи допомагають вивчити сутність досліджуваного предмету та аргументувати думку автора щодо окресленої проблеми. Наукова новизна роботи полягає у тому, що здійснено аналіз інформачійно-аналітичних документів, які публікуються на вебсайті Вінницької міської ради для комунікаџї з територіальною громадою та встановлено значимість інформаційно-аналітичних документів у документно-комунікаційній системі органів місиевого самоврядування; визначено основні інформачійно-аналітичні документи через які відбувається діалог з територіальною громадою та розглянуто процеси оптимізації інформування населення органами місиевого самоврядування. Висновки. Представлені у статті результати аналізу інформачійноаналітичних документів веб-сайту Вінницької міської ради дають підстави вважати, щчо робота органів місиевого самоврядування через опубліковані інформаційно-аналітичні документи на вебсайтах є дуже важливою для встановлення комунікації з територіальною громадою, вона якісно відрізнясться швидкістю і охопленням аудиторії, таким чином інструмент електронного урядування сприяє широкому і швидшому розвитку адміністративноїреформи та децентралізачії влади. Питання, які залишаються відкритими - робота із зберіганням таких документів, швидкість оброблення та реагування на запити.

Ключові слова: веб-сайт, електронні ресурси, публічні документи, інформаційні оголомення, органи місиевого самоврядування, територіальна громада, оприлюдненні відкриті дані, звернення громадян, адміністративні послуги, система місиевих петииій. 
Бойко Наталья Вячеславовна, аспирантка Национальной академии руководящих кадров культуры и искусств

\title{
ВЕБ-САЙТ КАК СОСТАВЛЯЮЩАЯ ДОКУМЕНТНО-КОММУНИКАЦИОННОГО ПРОСТРАНСТВА ОРГАНОВ МЕСТНОГО САМОУПРАВЛЕНИЯ: СТРУКТУРА, РЕСУРСЫ, СОДЕРЖАНИЕ
}

Цель работы. Исследовать структуру сайта и состав информационных ресурсов представленных на веб-сайте Винницкого городствого совета; сделать выводы о роли информационно-аналитических документов в документно-коммуникационной системе органов местного самоуправления. Методология исследования базируется на использовании общенаучных методах: анализа, синтеза, логического метода, метода визуализачии результатов исследования. Названые методы помогают изучить сущность изучаемого предмета и аргументировать позицию автора по очерченной тематике. Научная новизна работы состоит в том, что осуществлен анализ информационно-аналитических документов, которые публикуются на веб-сайте Винницкого городского совета для коммуникации с территориальными общинами и установить значимость информачионно-аналитических документов в документно-комуникационной системе органов местного самоуправления; определены основные информационно-аналитические документы через которые происходит диалог с территориальной общиной, а также изучены процессы оптимизации информирования населения органами местного самоуправления. Висновки. Представленные в статье результаты анализа информачионноаналитических документов веб-сайта Винницкого городского совета дают основания считать, что работа органов местного самоуправления через опубликованные информационно-аналитические документы на веб-сайтах является очень важной для налаживания коммуникации с территориальной общиной, она качественно отличается скоростью и охватом аудитории, таким образом инструмент електронного управления способствует широкому и быстрому развитию административной реформы и децентрализачии власти. Вопросы, которые остаются открытыми - робота с сохранением таких документов, скорость обработки и реагирования на запросьы.

Ключові слова: веб-сайт, электронные ресурсы, публичные документы, информационные объявления, органы местного самоуправления, территориальная община, обнародованные открытые данные, обращения граждан, административные услуги, система местных петиций.

\author{
Boiko Nataliia, \\ Candidate National Academy \\ of Culture and Arts Management
}

\section{WIB-SITE AS PART DOCUMETAL AND COMMUNICATION SPACE OF LOCAL GOVERNMENTS`AUTHORITIES: STRUCTURE, RESOURCES, CONTENT}

Purpose of the Article. Examine the structure of the website and composition of the information resources, which are presented on the website of Vinnytsia's city council; conclude the contribution of informativeanalytical documents in the documentation and communication system of local governments' authorities. The methodology of the research is based on the use of the general scientific methods: analysis, synthesis, logical approach, visualization technique of the result of the investigation. Named methods help to study the essence of the studied subject and to argue the author's position on the outlined topic. The scientific novelty of the work consists in realizing analysis of informative-analytical documents, which published on the website of Vinnytsia's city council for communication with local community and assessed the extent to concerned with informative-analytical documents in the documentation and communication system of local governments' authorities; identified primary informative-analytical documents through which the dialogue is happening with local community and also studied optimization process of public notice by local governments' authorities. Conclusions. Analysis results of informative-analytical documents on the Website of Vinnytsia's city council give reasons, that work of local governments' authorities by means published informative-analytical documents on the Web site are very important for establishing communication with local community, it is fraught with high-quality speed and media outreach, through this process the instrument of e-government promotes mass 
and high-speed development of administrative reform and decentralization of power. The questions, which are opened are the work with saving such documents, the speed with document processing, and the response of requests.

Key words: Web site, electronic source, published documents, informative notice, local governments' authorities, community, data releases, citizen petition, public services, a system of a local citizen petition.

Актуальність теми дослідження. Інформатизація суспільства - глобальний світовий неминучий процес. Засоби інформатизації направлені на розвиток усіх сфер соціальноекономічного життя. Повсякчас вони використовуються для полегшення обміну інформацією, розповсюдження повідомлень, широкої комунікації. Саме тому органи місцевого самоврядування в умовах адміністративної реформи та децентралізації влади переходять на електронні документи та інтернет ресурси для швидкого та ефективного спілкування з територіальною громадою. Веб-сайти районних органів місцевої влади стають масштабними інформаційними провідниками, де жителі регіону можуть дізнатись про значущі події, новини, замовити інформаційні послуги та скористатись електронними формами для запитів.

Мета роботи. Дослідити структуру сайту та зміст інформаційних ресурсів представлених на веб-сайті Вінницької міської ради.

Аналіз останніх досліджень і публікацій. Аналізу якісно нової системи комунікацій, що базується на можливостях інтернеттехнологій приділяється увага в публікаціях Л.Я. Філіпова [16], кандидатських дисертаціях і публікаціях В.В. Добровольської [1], О.А. Кравцової [3], О.В. Лаба [4], А.Т. Матвієнко [5], Л.О. Чекмарьова [17], Ю.П. Якимюк [18].

Так, Л.О. Чекмарьова досліджувала структуру веб-сайту обласної державної адміністрації як документальної системи, яка висвітлює нормотворчу діяльність державного органу; автором проаналізовано нормативноправову базу; досліджено детально структуру і зміст інформаційних ресурсів державних адміністрацій [17].

Л.Я. Філіпова займалася дослідженням інформаційних систем в новому комунікаційному середовищі, зокрема науковцем проаналізовано веб-сайти українських центрів науково-технічної інформації як дієвий комунікаційний засіб в сучасному інформаційно- комунікаційному просторі [16].

Виклад основного матеріалу. Державна політика України у сфері місцевого самоврядування спирається на інтереси жителів територіальних громад і передбачає децентралізацію влади - тобто передачу від органів виконавчої влади органам місцевого самоврядування значної частини повноважень, ресурсів та відповідальності. В основу цієї політики закладено положення Європейської хартії місцевого самоврядування [2].

Відповідно до Указу Президента України «Про заходи щодо впровадження Концепції адміністративної реформи в Україні» від 22 липня 1998 року № 810/98 в Україні відбуваються реформи децентралізації влади, перебудови адміністративно-територіального устрою, розвитку місцевого самоврядування, які активно почали формуватися на усіх рівнях з 2014 року [11].

У квітні 2014 року уряд схвалив основний документ - Концепцію реформування місцевого самоврядування та територіальної організації влади. Після цього був затверджений План заходів щодо іiі реалізації, які дали старт реформі.

Влада вінницького регіону одна 3 перших почала запроваджувати концепцію адміністративної реформи за допомогою програми «U-LEAD з Свропою», що фінансується Свропейським Союзом та його країнами-членами Данією, Естонією, Німеччиною, Польщею і Швецією. На Вінниччині станом на 19.07.2019 створено 42 об'єднані територіальні громади з 490 існуючих територіальних громад, розвиток за підтримки програми продовжується надалі.

Діяльність Вінницької міської Ради представлено територіальній громаді на офіційному веб-сайті http://www.vmr.gov.ua. Сайт забезпечує обізнаність жителів міста та регіону про найважливіші події через оприлюднені електроні інформаційно-аналітичні докумен- 
ти та допомагає їм здійснювати самоуправління за допомогою відкритого діалогу з місцевими депутатами та працівниками органів місцевого самоврядування.

Веб-сайт - сукупність даних, електронної (цифрової) інформації, інших об’єктів авторського права і (або) суміжних прав тощо, пов'язаних між собою і структурованих у межах адреси веб-сайту і (або) облікового запису власника цього веб-сайту, доступ до яких здійснюється через адресу мережі Інтернет, що може складатися 3 доменного імені, записів про каталоги або виклики і (або) числової адреси за Інтернет-протоколом [8].

Веб-сайт Вінницької міської ради представляє собою сукупність опублікованих електронних інформаційно-аналітичних документів, які висвітлюють щоденну роботу виконавчого апарату Вінницької міської ради та допомагають громадян (територіальним громадам) приймати участь у здійснення народовладдя. Документи поєднанні за змістом i характером пошуку, полегшують роботу із надання інформаційно-аналітичних послуг користувачам веб-сайту. Практично, сайт - це електронна дошка оголошень (електронний інформаційний стенд), а в глибшому своєму розумінні - електронна бібліотека публічних документів, за допомогою яких населення регіону залучають до співпраці.

На сайті опубліковані інформаційні оголошення (новини) про громадське життя регіону, сторінка для підтримки учасників АТО, форми для створення електронних петицій та звернення громадян, опублікована звітність громадських ініціатив регіону, представлені інформаційні довідки щодо виборів (інформація щодо територіальних виборчих округів, депутатів, їх партійної приналежності), концепції розвитку регіону, документи щодо технічної підтримки створення ОСББ, програми розвитку, оприлюдненні відкриті дані виконавчих органів Вінницької міської ради та комунальних підприємств міста, інформативні дані про екологічний стан регіону та енергоресурси (пам'ятки щодо їх зберігання та ефективного використання), звітність щодо публічних закупівель, опубліковані документи Вінницької міської ради щодо громадського життя, звітність про бюджет вінницького регіону.
Інформаційні оголошення подані у вигляді коротких текстових повідомлень, які містять стислу інформацію щодо подій регіону. У дійсності, головна сторінка сайту являє собою інформаційний стенд в електронному вигляді. Інформаційний стенд $є$ оптимальним засобом надання різного роду інформації 3 максимальною швидкою можливістю іiі заміни (оновлення). Електронний інформаційний стенд $є$ найзручнішим технічним засобом висвітлення оперативної аналітичної інформації органів місцевого самоврядування. Його переваги очевидні:

- швидкість та зручність у використанні;

- можливість оприлюднити великий обсяг інформації за досить короткий термін;

- можливість швидко оновлювати великі масиви інформації;

- великий обсяг аудиторії водночас (майже не обмежена, за винятком технічної спроможності користувачів).

Сайт побудовано таким чином, що кожен мешканець міста може знайти максимально багато корисної інформації. Це безперечно посилює співробітництво між територіальною громадою і органами місцевого самоврядування. Прикладом може слугувати інформаційна довідка, яка знайомить населення регіону з графіком роботи, телефонами та розташуванням важливих для вирішення побутових питань служб міста. Таких, які забезпечують обслуговування житлових будинків та прибудинкових територій, обслуговування ліфтів, надають послуги електропостачання, холодного водопостачання та водовідведення, теплопостачання та гарячого водопостачання, здійснюють освітлення вулично-шляхової мережі та прибудинкових територій, прибирання та ремонт вулично-шляхової мережі, транспортне забезпечення.

Важливим засобом спілкування 3 містянами є Оприлюдненні відкриті дані виконавчих органів Вінницької міської ради та комунальних підприємств міста. Оприлюднення набору даних - завантаження набору даних розпорядником інформації та забезпечення доступу до нього держателем порталу після проходження модерації. Робота 3 даними прогресивний спосіб спілкування $з$ територі- 
альною громадою при якому відкриті дані вже є у відкритому та прямому доступі до використання, при цьому не потрібно подавати заявки, чекати відповіді і використовувати паперові носії. Дані публікуються на сайтах, де кожен користувач може скористатись інформацією без перешкод. Опридлюненні набори даних постійно коригуються Кабінетом Міністрів України і їх перелік постійно розширюється, а періодичність та порядок їх оприлюднення оновлюється згідно Постанови Кабінету Мiністрів України «Про затверження Положення про набори даних, які підлягають оприлюденню у формі відкритих даних» від 21 жовтня 2015 року № 835 [10].

Оприлюдненні відкриті дані публікуються згідно Рішення виконавчого комітету міської ради від 20.07.2017 р. № 1627 «Про приєднання Вінницької міської ради та її виконавчих органів до Міжнародної Хартії відкритих даних» [10]. У 2017 році Вінниця приєдналась до Міжнародної Хартії відкритих даних і підписала Меморандум про співпрацю в рамках реалізації пілотного проекту щодо відкритих даних [6], згідно якого було створено план дій 3 реалізації принципів Міжнародної Хартії відкритих даних, який виконується згідно Розпорядження міського голови від 18.10.2017 p. № 181-Р «Про заходи щодо реалізації принципів Міжнародної Хартії відкритих даних та розвитку відкритих даних» [12]. Для роботи 3 населенням і реалізації проекту створено Портал відкритих даних Вінниці (розпорядження міського голови від 17.05.2018 р. № 70-р «Про впровадження Порталу відкритих даних Вiнниці») [9].

Оприлюднені відкриті дані фактично являються інформаційним бюлетенем, за допомогою якого висвітлюється робота виконавчого апарату органів місцевого самоврядування. Дані поділені між департаментами за сферою використання. Департаменти оприлюднюють усі відомості, які можуть містити результати роботи виконавчого апарату. Наприклад, плани закупівель, переліки діючих договорів, звіти про використання бюджетних коштів (e-data), реєстри укладених договорів, звіти про заборгованість, звіти про фінансові результати. При запроваджені адміністративної реформи, введення політики оприлюднення відкритих даних $є$ основою для демонстрації прямого прозорого діалогу з територіальною громадою і небажанням приховувати від містян важливих повідомлень.

Важливим $\epsilon$ те, що мешканці регіону можуть давати зворотній зв'язок органам місцевого самоврядування для вдосконалення дії Порталу. Таким чином, відбувається обмін інформацією з обох сторін. Громадяни можуть подавати пропозиції щодо оприлюднення нових наборів даних, вдосконалення існуючих наборів, а також інформацію про розроблені сервіси, надсилаючи зворотній зв'язок на електронну адресу адміністратора Порталу, яку подано на веб-сайті Вінницької міської ради.

Особливо важливою є робота зі зверненнями громадян. Під зверненнями громадян слід розуміти викладені в письмовій або усній формі пропозиції (зауваження), заяви (клопотання) і скарги. Звернення громадян - найпопулярніший засіб діалогу між місцевою владою і територіальною громадою. Особливою формою колективного звернення громадян до Президента України, Верховної Ради України, Кабінету Міністрів України, органу місцевого самоврядування $є$ електронна петиція, яка подається та розглядається в порядку передбаченому статтею 23 Закону України «Про звернення громадян» № 393/96-ВР від 02 жовтня 1996 року [13].

Звернення може бути усним чи письмовим. Усне звернення викладається громадянином на особистому прийомі або за допомогою засобів телефонного зв'язку через визначені контактні центри, телефонні «гарячі лінії» та записується (реєструється) посадовою особою. Письмове звернення надсилається поштою або передається громадянином до відповідного органу, установи особисто чи через уповноважену ним особу, повноваження якої оформлені відповідно до законодавства. Письмове звернення також може бути надіслане з використанням мережі Інтернет (через веб-сайти), засобів електронного зв'язку (електронне звернення).

На веб-сайті Вінницької міської ради зручно налаштована робота 3 усіма видами звернень громадян. Форма для заповнення петицій та звернень розташована на головній сторінці сайту, що говорить про відкритість влади в ре- 
гіоні і здатність іти на зустріч до населення. Зауважимо, що в Законі «Про звернення громадян» не зазначено про таку вимогу, що зайвий раз доводить про прогресивність регіону і налаштованість на розвиток адміністративної реформи і відкритим спілкуванням з територіальними громадами. На сторінці подана детальна інформація щодо особистого прийому громадян міським головою, вимог до запитів та способи звернень, адреси для особистих звернень до депутатів та графіки прийому, робота прямих телефонних ліній. Поряд подано публічні відповіді за зверненнями громадян на які міська влада подала вичерпні відповіді. Biнницька міська рада на інформаційній сторінці консультує щодо усіх форм звернень (усні та письмові) і надає на сайті розгорнуту інформацію громадянам. До того ж, подані дані про зону відповідальності кожного з депутатів (охоплена сфера питань у якій той чи інший депутат має можливість допомогти).

На веб-сайті є посилання на єдину систему місцевих петицій. Сдина система місцевих петицій створена в рамках програми «Електронне врядування задля підзвітності влади та участі громади» (EGAP), що фінансується Швейцарською Конфедерацією та виконується фондом Східна Європа у партнерстві 3 Державним агентством $з$ питань електронного врядування.

На сторінці платформи модератори опубліковують петиції збір підписів, яких триває; петиції, які знаходяться на розгляді; а також петиції на які вже подано відповіді. Крім того, тут можна побачити платформу електронної демократії. На платформі поєднанні місцеві петиції; громадській бюджет, який надає можливість мешканцям пропонувати свої проекти місцевого розвитку; відкрите місто для взаємодії мешканців 3 місцевою владою та комунальними підприємствами/органами самоорганізації населення; консультації з громадськістю, який надає органам місцевої влади можливість залучати пропозиції мешканців щодо питань розвитку міст та громад, організовувати обговорення проектів документів перед їх розглядом та схваленням, проводити місцеві опитування в різних формах 3 метою вивчення думки активної частини мешканців міст.

Характерною рисою платформи є покриття усієї країни. Будь-яке місто за бажанням може приєднатися до платформи. Та провідними регіонами проекту є Вінницька, Волинська, Дніпропетровська та Одеська області. Метою створення платформи $є$ допомога органам місцевого самоврядування щодо роботи 3 електронними петиціями на єдиному високому рівні якості обслуговування громадян із відповідною нормативно-правовою базою із якісною уніфікованою системою, що охоплює усі країни для вирішення найбільш нагальних проблем громад. Крім того, партнери програми користуються єдиною нормативно-правовою базою із визначенням вимог до електронної ідентифікації громадян, збору підписів, переліку інформації, що збирається про особу тощо. Уніфікована система для усіх партнерів програми дасть змогу містам заощаджувати кошти на розроблення власних електронних систем і витрачати на більш нагальні проекти територіальної громади.

Привертає увагу розділ веб-сайту Вінницької міської ради - ініціатива «Громадська участь», за допомогою якої місцева влада активно долучає населення до громадських обговорень. Громадські обговорення (громадські слухання) - це можливість територіальної громади Вінницького регіону прийняти безпосередню участь у здійсненні місцевого самоврядування, тобто порушені питань та внесені пропозицій щодо питань місцевого значення.

Органи місцевого самоврядування Biнницького регіону інформують жителів міста про загальноміські і локальні проекти, які винесені на обговорення. Тут подано інформацію про нормативно-правове забезпечення кожного громадського обговорення, порядок ініціювання, підготовки та проведення громадського обговорення та громадських слухань, розклад усіх громадських обговорень та громадських слухань та їх результатів, що проводить Вінницька міська рада у вигляді інформаційних оголошень 3 описом винесеної до обговорення проблематики.

Значне досягнення у сфері надання інформаційних та адміністративних послуг $є$ «Прозорий офіс» Вінницької міської ради, сторінка якого знаходиться на сайті Вінницької міської ради. Це кардинально новий спосіб спілкування між місцевою владою і територіальної громадою. Його особливість полягає в 
тому, що у робочому органі виконавчого комітету міської ради зосереджені усі послуги, які надають адміністративні державні органи за єдиним алгоритмом оформлення документів. Про ефективність центру говорить той факт, що в 2012 році було відкрито 3 територіальні відділення Центру. Крім адміністративних послуг, населення регіону може звернутись до Центру із соціальних та господарськогоадміністративних послуг (соціальний захист та соціальне страхування, оформлення пенсій та житлових субсидій, призначення соціальних виплат та пільг, надання матеріальних допомог, оформлення технічних умов та дозволів на під'єднання до мереж газопостачання).

Наукова новизна роботи полягає у тому, що здійснено аналіз інформаційноаналітичних документів, які публікуються на веб-сайті Вінницької міської ради для комунікації з територіальною громадою та розглянуто процеси оптимізації інформування населення органами місцевого самоврядування.

Висновки. Представлені на сайті інформаційно-аналітичні документи - це великий масив інформації, за допомогою яких виникає якісний соціокомунікаційний простір і відбувається комунікація між територіальною громадою та органами місцевого самоврядування. Вони широко використовується владою для ознайомлення населення 3 різними новинами і подіями. За допомогою таких документів органи місцевого самоврядування ведуть діалог 3 населенням, дотримуючись принципу прозорості, доступності та повноти інформації. Інформаційно-аналітичні документи використовуються щоденно у роботі місцевої влади завдяки простоті викладу та подальшого використання інформації. Безперечно є невід'ємною частиною системи службової документації органів місцевого самоврядування в умовах адміністративної реформи та децентралізації влади, забезпечуючи принцип гласності місцевої влади.

3 огляду на вищевикладене веб-сайти органів місцевого самоврядування повинні постійно слідкувати не тільки за оновленням інформації та наповненням веб-сторінки, розширенням інформативних, консультативних та корисних даних, але й оптимізувати роботу iз структурою сайту, його будовою, систематизацією матеріалів.

\section{Список використаних джерел}

1. Добровольська В.В. Державна політика в галузі культури України: стан та розвиток системи управління документацією: монографія / Вікторія Добровольска; М-во культури України, Нац. акад. керів. кадрів культури і мистецтв. - Київ: НАКККіМ, 2017. - 233 с.

Європейська хартія місцевого самоврядування від 15.10.1985. Страсбург, 1985. URL: https://zakon4. rada.gov.ua/laws/show/994_036.

Кравцова О.А. Архівний портал ЮНЕСКО: засади створення, структура, інформаційний ресурс: автореф. дис. на здобуття наук. ступеня канд. іст. наук: спец. 27.00.02 / О.А. Кравцова; Держ. акад. керів. кадрів культури і мистецтв. - Київ, 2009. - 19 с.

Лаба О. Електронне діловодство: проблеми та перспективи розвитку / О. Лаба // Студії з архівної справи та документознавства. 2011. - Т.2. - С. 53-56.

Матвієнко А.Т. Документально-інформаційне забезпечення туристичної галузі в Україні: соціальнокомунікаційний аспект автореф. дис. на здобуття наук. ступеня канд. наук із соціальних комунікацій: спец. 27.00.02 «Документознавство, архівознавство» / А.Т. Матвієнко; Нац. акад. керів. кадрів культури і мистецтв. - Київ, 2012. - 15 с.

Меморандум про співпрацю в рамках реалізації пілотного проекту щодо відкритих даних між Виконавчим комітетом Вінницької міської ради, Державним агентом з питань електронного урядування України та Фондом «Свразія» (Проект міжнародної технічної допомоги «Прозорість та підзвітність у державному управлінні та послугах (TAPAS)»). - Вінниця, 2017. - 6 с.

Мороз О. Досвід Польщі в рамках реформи децентралізації / О. Мороз // Місцеве самоврядування - К., 2017. - №11. - С. 23-24.

Про авторське право і суміжні права: Закон України від 23.12.1993 № 3792-XII. Київ, 1993. URL: https://zakon.rada.gov.ua/laws/show/ru/3792-12/ed20170426.

Про впровадження Порталу відкритих даних Вінниці: Розпорядження міського голови Вінницької міської ради від 17.05.2018 № 70-p. Вінниця, 2018. URL: https://www.vmr.gov.ua/Docs/ MajorOrdersR/2018/\%E2\%84\%9670-\%D1\%80\%2017-05-2018.pdf.

Про затвердження Положення про набори даних, які підлягають оприлюдненню у формі відкритих 
даних: Постанова Кабінету Міністрів України від 21.10.2015 № 835. Київ, 2015. URL: https://zakon.rada. gov.ua/laws/show/835-2015-\%D0\%BF\#n12.

Про заходи щодо впровадження Концепції адміністративної реформи України: Указ Президента від 22.07.1998 № 810/98. Київ, 1998. URL: http://zakon3.rada.gov.ua/laws/show/810/98.

Про заходи щодо реалізації принципів Міжнародної Хартії відкритих даних та розвитку відкритих даних: Розпорядження міського голови Вінницької міської ради від 18.10.2017 № 181-Р. Вінниця, 2017. URL: https://www.vmr.gov.ua/Docs/MajorOrdersR/2017/\%E2\%84\%96181-\%D1\%80\%2018-10- 2017\%20 \%D0\%9F\%D1\%80\%D0\%BE\%20\%D0\%B7\%D0\%B0\%D1\%85\%D0\%BE\%D0\%B4\%D0\%B8.pdf.

Про звернення громадян: Закон України від 02.10.1996 № 393/96-BP. Київ, 1996. URL: https:// zakon2.rada.gov.ua/laws/show/393/96-\%D0\%B2\%D1\%80.

Про приєднання Вінницької міської ради та її виконавчих органів до Міжнародної Хартії відкритих даних: Рішення виконавчого комітету Вінницької міської ради від 20.07.2017 № 1627. Вінниця, 2017. URL: $\quad$ https://www.vmr.gov.ua/Docs/ExecutiveCommitteeDecisions/2017/\%E2\%84\%961627\%2020-07$2017 \% 20 \% \mathrm{D} 0 \% 9 \mathrm{~F} \% \mathrm{D} 1 \% 80 \% \mathrm{D} 0 \% \mathrm{BE} \% 20 \% \mathrm{D} 0 \% \mathrm{BF} \% \mathrm{D} 1 \% 80 \% \mathrm{D} 0 \% \mathrm{~B} 8 \% \mathrm{D} 1 \% 94 \% \mathrm{D} 0 \% \mathrm{~B} 4 \% \mathrm{D} 0 \% \mathrm{BD} \% \mathrm{D}$ 0\%B0\%D0\%BD\%D0\%BD\%D1\%8F.pdf.

Про схвалення Концепції реформування місцевого самоврядування та територіальної організації влади в Україні: Розпорядження Кабінету Міністрів України від 01.04.2014 № 333-р. Київ, 2014. URL: https://zakon5.rada.gov.ua/laws/show/333-2014-\%D1\%80.

Філіпова Л. Аналіз контенту веб-сайтів українських центрів науково-технічної інформації 3 точки зору використання інтернет-сервісів / Л. Філіпова // Вісник книжкової палати. 2012. - № 10. - С. 22-28.

Чекмарьова Л.О. Веб-сайт обласної державної адміністрації України як документальноінформаційна система: засади функціонування, структура, зміст: 07.00.10 - документознавство, архівознавство Дис. ... канд. іст. наук КИїВ - 2008. Робота виконана в Українському науково-дослідному інституті архівної справи та документознавства. - КИїВ, 2012. - 227 с.

Якимюк Ю.П. Комунікаційна система документаційного забезпечення управління вищим навчальним закладом: [монографія] / Ю.П. Якимюк. - Київ: Університет «Україна», 2011. - 191 с.

\section{References}

1. Dobrovolska V. (2017). Public policies on culture of Ukraine: status and development of the management system. Kyiv: NAKKKiM [in Ukrainian].

European CharterofLocalSelf-Government.(1985).URL:https://zakon4.rada.gov.ua/laws/show/994_036 [in Ukrainian].

Kravtsov, O.A. (2009). Archives portal of UNESCO: basis for the creation, structure, information resource: Extended abstract of candidate's thesis. Kyiv [in Ukrainian].

Laba O. (2011). E-government: problems and prospects of development. Studii z arkhivnoi spravy ta dokumentoznavstva, 2, 53-56 [in Ukrainian].

Matviienko A.T. (2012). Documental and informative achievement of tourism sector in Ukraine: social and communicative aspect: Extended abstract of candidate`s thesis. Kyiv [in Ukrainian].

Memorandum of cooperation as a part of the implementation of pilot project in relation to Open Data between city government of Vinnytsia`s city council, State agency of e-government of Ukraine and Eurasia Foundation (The project of international technical assistance «Transparency and accountability of public administration and services (TAPAS)»). (2017) [in Ukrainian].

Moroz O. (2017). Experience of Poland as part of decentralization reform. Mistseve Samovriaduvannia, 11, 23-24 [in Ukrainian].

URL:

Law of Ukraine literary property and allied rights. (1993).

[in Ukrainian]. https://zakon.rada.gov.ua/laws/show/ru/3792-12/ed20170426

Order of mayor of Vinnytsia's city council on implementation of the Portal of Vinnytsia's Open Data. (2018). URL: https://www.vmr.gov.ua/Docs/MajorOrdersR/2018/\%E2\%84\%9670-\%D1\%80\%2017-05-2018. pdf [in Ukrainian].

Order of Justice ministry of Ukraine on approval Regulation of datasets, which shall be made publicly available as Open Data. (2015). URL: https://zakon.rada.gov.ua/laws/show/835-2015-\%D0\%BF\#n12 [in Ukrainian].

Decree of the President on activities related to the implementation of the Concept of administrative reform of Ukraine. (1998). URL: http://zakon3.rada.gov.ua/laws/show/810/98 [in Ukrainian].

Order of mayor of Vinnytsia`s city council on activities of implementation of the principles of International Charter of Open Data and developing of Open Data. (2017). URL: https://www.vmr.gov.ua/Docs/ 
MajorOrdersR/2017/\%E2\%84\%96181-\%D1\%80\%2018-10-2017\%20\%D0\%9F\%D1\%80\%D0\%BE\%20\%D 0\%B7\%D0\%B0\%D1\%85\%D0\%BE\%D0\%B4\%D0\%B8.pdf [in Ukrainian].

Law of Ukraine on citizen petition. (1996). URL: https://zakon2.rada.gov.ua/laws/show/393/96$\% \mathrm{D} 0 \% \mathrm{~B} 2 \% \mathrm{D} 1 \% 80$ [in Ukrainian].

Decision of the Executive Committee of Vinnytsia's city council on adherence Vinnytsia`s city council and the Executive Committee to International Charter of Open Data. (2017). URL: https://www.vmr.gov.ua/Docs/Ex ecutiveCommitteeDecisions/2017/\%E2\%84\%961627\%2020-07-2017\%20\%D0\%9F\%D1\%80\%D0\%BE\%20 \%D0\%BF\%D1\%80\%D0\%B8\%D1\%94\%D0\%B4\%D0\%BD\%D0\%B0\%D0\%BD\%D0\%BD\%D1\%8F.pdf. [in Ukrainian].

Order of Justice ministry of Ukraine on endorsed the Concept of local government reform and territorial organisation of government in Ukraine. (2014). URL: https://zakon5.rada.gov.ua/laws/show/333-2014$\%$ D $1 \% 80$ [in Ukrainian].

Filipova L. (2012). Analysis of content of the web site of Ukrainian centers of scientific \& technical information with regard to using of Internet-services, 10, 22-28 [in Ukrainian].

Chekmarova L.O. (2012). The web site of region state administration of Ukraine as documental \& informative system: foundation of the operation, structure, content: Extended abstract of candidate's thesis. Kyiv [in Ukrainian].

Yakymiuk Yu.P. (2011). Communicative system of documental enforcement of management of higher education institution. Kyiv: Universytet «Ukraina» [in Ukrainian]. 